\title{
Distribution of actinomycetes in different soil ecosystems and effect of media composition on extracellular phosphatase activity
}

\author{
Ghorbani-Nasrabadi, R. ${ }^{1}$, Greiner, R. ${ }^{2 *}$, Alikhani, H. A. ${ }^{3}$, Hamedi, J. ${ }^{4}$, Yakhchali, B. ${ }^{5}$ \\ ${ }^{I}$ Department of Soil Science, College of Soil and Water,Gorgan University of Agricultural Sciences \& Natural resources, Iran. \\ ${ }^{2}$ Max Rubner-Institut, Federal Research Institute of Nutrition and Food, Department of Food Technology and Bioprocess \\ Engineering, Haid-und-Neu-Strasse 9, 76131 Karlsruhe, Germany, Phone: ++49 (0) 721 / 6625300 Fax: ++49 (0) $721 / 6625$ \\ 303. ${ }^{3}$ Department of Soil Science, College of Agricultural Engineering and Technology, University of Tehran, Iran. ${ }^{4}$ Department \\ of Microbiology, College of Science, University of Tehran, Iran. ${ }^{5}$ Industrial and Environmental Biotechnology Department, \\ National Institute of Genetic Engineering and Biotechnology, Tehran, Iran. Corresponding author: ralf.greiner@mri.bund.de
}

\begin{abstract}
Actinomycetes are widely distributed in different habitats and involved in important processes. Therefore, evaluation of their distribution is important in understanding their ecological role. Ninety seven samples were taken from different soil ecosystems (forest, pasture, rain-fed and irrigated cultivated land) located in various climatic zones in the province of Golestan, Northeast Iran. The number of actinomycetes as well as $\mathrm{pH}$ value, organic carbon (OC) and soil salinity expressed as electrical conductivity (EC) showed significant differences in the soil ecosystems under investigation. The number of actinomycetes decreased from $2.86 * 10^{6} \mathrm{cfu} \mathrm{g}^{-1}$ in irrigated cultivated land to $7 * 10^{5} \mathrm{cfu} \mathrm{g}^{-1}$ in pasture $(p<0.01)$. In pastures, the number of actinomycetes was negatively correlated with EC $(\mathrm{r}=-$ $0.60, \mathrm{n}=15, p<0.001)$ and $\mathrm{pH}(\mathrm{r}=-0.59, \mathrm{n}=15, p<0.001)$. In other soil ecosystems under investigation no significant correlations between soil $\mathrm{pH}, \mathrm{OC}$ and $\mathrm{EC}$ and the number of actinomycetes could be found. In forest soils, the number of actinomycetes was significantly dependent $(p<0.05)$ on climate. A significantly higher population was observed under semi-arid conditions compared to all other climatic zones (humid, sub-humid, Mediterranean). Because many soil microorganisms are able to transform different forms of insoluble organic and inorganic phosphorus into a soluble form suitable for plant uptake, the capacity of the isolated actinomycetes to secrete phosphatase activity was determined under laboratory conditions. A huge variation in the capacities to produce acid and alkaline phosphatases among the different isolates was observed. These enzyme activities and the capacities to hydrolyze phytate in the fermentation broth were significantly dependent on medium composition. In general, substitution of arginine and glycerol in the modified glycerol arginine medium (MGA) with other nitrogen and carbon sources resulted in a significant reduction of phytate dephosphorylation.
\end{abstract}

Keywords: Actinomycetes, land use, phosphatase, phosphorus, phytate, phytate-degrading enzyme 


\section{Introduction}

Phosphorus (P) is an essential element for all organisms and in soil ecosystem phosphorus is often the most limiting nutrient for plant growth. Soil $\mathrm{P}$ can exist in organic and inorganic forms. Organic $\mathrm{P}$ usually comprises $29-65 \%$ of total soil $\mathrm{P}$, but in some organic soils organic $\mathrm{P}$ can account for up to $90 \%$ of total P (Harrison, 1987). In general the amount of soil $\mathrm{P}$ is more than sufficient for the requirement of soil microorganisms and plants. However, only a minor amount of the total soil $\mathrm{P}$ is readily available to plants and microorganisms. Therefore, $\mathrm{P}$ fertilizers based on rock phosphate have got a very important role in agricultural production. Predictions based on the current use of rock phosphate assume a depletion of global high quality rock phosphate reserves by 2100 (van Vuuren et al., 2010). This concern and the increasing demand for low input agriculture has revealed that a better understanding of the plant-soilmicrobial $\mathrm{P}$ cycle is of utmost importance.

Numerous reports have been published on the phosphate solubilizing microorganisms (PSM) such as Bacillus subtilis, Pseudomonas sp. (Rodríguez and Fraga, 1999), Mesorhizobium sp. (Peix et al., 2001), Penicillium sp. and arbuscular mycorrhizal fungi (Ouahmane et al., 2007). Recently the capability of P solubilization (Ghorbani-Nasrabadi et al., 2012) by actinomycetes was reported. However, most of the studies on actinomycetes have been focused on their capability to solubilize inorganic phosphates. There is only one single study on the capability of actinomycetes to hydrolyze phytate, the predominant form of organic P in soils (Ghorbani-Nasrabadi et al., 2012). Actinomycetes are widely distributed in different habitats and involved in important processes. They are not only able to survive under extreme soil condition such as low level of moisture or high salinity, but actinomycetes are also reported to promote plant growth (Hamdali et al., 2008). Therefore, evaluation of their distribution is important in understanding their ecological role. Several studies have shown that soil properties are more important for bacterial soil composition than vegetation (Bossio et al., 2005). A comparison among four different land uses (cultivated, pasture, pine plantation and mixed wood forest) in Georgia, USA revealed for example that actinobacteria were more prevalentin pasture and cultivated soils (Lauber et al., 2009). In addition, Burck et al. (2003) reported that actinomycetes population is higher in bacterial communities inagricultural land compared to forest soils when analyzing forest, pasture and sugar cane plantations in different countries. Furthermore, actinomycetes population was reported to increase after conversion of land use from forest to agriculture; a behavior common to fungi, but not to bacteria (Burck et al., 2003; Fierer et al., 2009).

The objective of this work wasto study the effect of soil properties and land use on actinomycetes population as well as the capability of actinomycetes to produce extracellular phosphate activity (including phytatedegrading activity) and its dependence on medium composition.

\section{Materials and Methods}

\subsection{Soil sampling}

Ninety seven samples were taken from different soil ecosystems (forest, pasture, rain-fed and irrigated cultivated land) located in various climatic zonesin the province of Golestan, Northeast Iran.

\subsection{Measurement of soil chemical and physical properties}

Soil samples were air-dried, passed through a $2 \mathrm{~mm}$ sieve and thereafter dried in an oven at $105^{\circ} \mathrm{C}$ for 24 hrs for chemical and physical analysis. Soil texture was determined by the Bouyoucos hydrometer method (Gee and Bauder, 1986). The pH-values of the soils were measured in saturated past (McLean, 1982), whereas electrical conductivity (EC) was determined 
in the extract of the water saturated past (Ryan et al., 1999). Organic Carbon (OC) was estimated by the potassium dichromate oxidation method (Nelson and Sommers, 1982).

\subsection{Enumeration of actinomycetes population}

The dilution plate method was used to enumerate common actinomycetesin the soils. Soil samples were air-dried for $72 \mathrm{hrs}$ followed by incubation at $40^{\circ} \mathrm{C}$ for 16 hours (Williams and Wellington, 1982). The treated soil samples were spread in a serial dilution onto glycerol arginine agar (GAA) $\left(1 \mathrm{~g} \mathrm{~L}^{-1} \mathrm{~L}\right.$-arginine, $12.5 \mathrm{~g} \mathrm{~L}^{-1}$ glycerol, $1 \mathrm{~g} \mathrm{~L}^{-1} \mathrm{~K}_{2} \mathrm{HPO}_{4}, 1 \mathrm{~g} \mathrm{~L}^{-1} \mathrm{NaCl}, 0.5$ $\mathrm{g} \mathrm{L}^{-1} \mathrm{MgSO}_{4} \times 7 \mathrm{H}_{2} \mathrm{O}, 0.01 \mathrm{~g} \mathrm{~L}^{-1} \mathrm{FeSO}_{4} \times 6 \mathrm{H}_{2} \mathrm{O}, 0.001$ $\mathrm{g} \mathrm{L}^{-1} \mathrm{CuSO}_{4} \times 5 \mathrm{H}_{2} \mathrm{O}, 0.001 \mathrm{~g} \mathrm{~L}^{-1} \mathrm{MnSO}_{4} \times \mathrm{H}_{2} \mathrm{O}, 0.001$ $\mathrm{g} \mathrm{L}^{-1} \mathrm{ZnSO}_{4} \times 7 \mathrm{H}_{2} \mathrm{O}, 15 \mathrm{~g} \mathrm{~L}^{-1}$ agar (El-Nakeeb and Leachevalier, 1963) supplemented with $100 \mu \mathrm{g} \mathrm{mL}$ ${ }^{1}$ cycloheximide and the Petri dishes were incubated for 14 days at $28^{\circ} \mathrm{C}$. Dry powdery or velvety colonies with limiting growth were considered as actinomycetes.

\subsection{Effect of different nitrogen sources on phytate degradation}

Arginine was replaced in the modified glycerol arginine medium (MGA) $\left(1 \mathrm{~g} \mathrm{l}^{-1} \mathrm{~L}\right.$-arginine, $12.5 \mathrm{~g} \mathrm{l}^{-1}$ glycerol, 4 $\mathrm{g} \mathrm{l}^{-1}$ Na-phytate, $1 \mathrm{~g} \mathrm{l}^{-1} \mathrm{CaCl}_{2}, 1 \mathrm{gl}^{-1} \mathrm{NaCl}, 0.5 \mathrm{~g} \mathrm{l}^{-1} \mathrm{MgSO}_{4}$ x $7 \mathrm{H}_{2} \mathrm{O}, 0.01 \mathrm{~g} \mathrm{l}_{-1} \mathrm{FeSO}_{4}$ x $6 \mathrm{H}_{2} \mathrm{O}, 0.001 \mathrm{~g} \mathrm{l}^{-1} \mathrm{CuSO}_{4}$ x $5 \mathrm{H}_{2} \mathrm{O}, 0.001 \mathrm{~g}_{-1} \mathrm{MnSO}_{4} \times \mathrm{H}_{2} \mathrm{O}, 0.001 \mathrm{~g} \mathrm{l}^{-1} \mathrm{ZnSO}_{4} \times 7$ $\left.\mathrm{H}_{2} \mathrm{O}\right)$ by different other nitrogen sources $\left(\left(\mathrm{NH}_{4}\right)_{2} \mathrm{SO}_{4}\right.$, $\mathrm{NaNO}_{3}, \mathrm{NH}_{4} \mathrm{NO}_{3}$, malt extract, meat extract, soybean meal) in a concentration of $0.1 \%(\mathrm{w} / \mathrm{v})$.

Furthermore, glycerol in the MGA medium was replaced by different carbon sources. Simple sugars such as glucose, fructose, sucrose, lactose, and maltose were added in a concentration of $1 \%(\mathrm{w} / \mathrm{v})$ and complex carbon sources such as pea flour and maltodextrin in a concentration of $0.5 \%(\mathrm{w} / \mathrm{v})$.

\subsection{Standard phytate-degrading enzymes assay}

Spectrophotometric assay was carried out in a total volume of $2 \mathrm{ml}$ at $37^{\circ} \mathrm{C}$ for $30 \mathrm{~min}$ in $0.1 \mathrm{M}$ Tris-
$\mathrm{HCl}(\mathrm{pH}$ 7.4) and ammonium acetate $(\mathrm{pH} 5)$ buffer containing $10 \mathrm{mM}$ sodium phytate. The enzymatic reactions were started by the addition of $50 \mu \mathrm{L}$ of enzyme to the assay mixtures. The liberated Pi was measured according to Greiner et al. (1998). The reaction was terminated by the addition of $1.5 \mathrm{ml}$ of freshly prepared acetone, $5 \mathrm{~N}$ sulfuric acid and 10 $\mathrm{mM}$ ammonium molybdate reagent $(2: 1: 1 \mathrm{v} / \mathrm{v})$ and there after $100 \mu \mathrm{l}$ of $1 \mathrm{M}$ of citric acid were added. Absorbance was determined at $355 \mathrm{~nm}$. A calibration curve was prepared from 5 to $600 \mathrm{mM}$ phosphate. Phytate degrading activity (U) was defined as the amount of enzyme that released $1 \mu \mathrm{mol}$ phosphate per $\min$.

\section{6. myo-Inositol phosphate analysis by HPLC}

Quantification of phytate and other myo-inositol phosphates was performed by ion pair chromatography (Greiner et al., 1998). In brief, the medium was acidified with $\mathrm{HCl}$ to give a final concentration of $2.4 \%$. $2 \mathrm{~mL}$ of the acidified medium were diluted $1: 25$ with water and applied to a column $(0.7 \times 15 \mathrm{~cm})$ containing AG1-X8, 100-200 mesh resin. The column was washed with $25 \mathrm{ml}$ of water and $25 \mathrm{ml}$ of $25 \mathrm{mM}$ $\mathrm{HCl}$. Then myo-inositol phosphates were eluted with 20 $\mathrm{ml}$ of $2 \mathrm{M} \mathrm{HCl}$. The eluate obtained was concentrated in a vacuum evaporator to dryness and the residue was solved in $1 \mathrm{~mL}$ water. $20 \mu \mathrm{L}$ of the samples were chromatographed on Ultrasep ES 100 RP18 ( 2 x 250 $\mathrm{mm})$. The column was run at $45^{\circ} \mathrm{C}$ and $0.2 \mathrm{~mL} \mathrm{~min}^{-1}$ of an eluant consisting of formic acid:methanol:water: tetrabutylammonium hydroxide (44:56:5:1.5 v/v), $\mathrm{pH}$ 4.25, as described by Sandberg and Ahderinne (1986). A mixture of the individual myo-inositol phosphate esters $\left(\mathrm{InsP}_{3}-\mathrm{InsP}_{6}\right)$ was used as a standard.

\subsection{Acid and alkaline phosphatase assay}

Acid and alkaline phosphatase activities were determined according to Greiner et al. (2003). $50 \mu \mathrm{L}$ of each samplewas added to $200 \mu \mathrm{L}$ of $100 \mathrm{mM}$ sodium acetate $\mathrm{pH} 5$ or glycine- $\mathrm{NaOH} \mathrm{pH} 10$ containing $1 \mathrm{mMp}$-nitrophenyl phosphate (pNPP) for acid or 
alkaline phosphatase activity, respectively and incubated at $37^{\circ} \mathrm{C}$ for 30 minutes. The reaction was terminated by addition of $1 \mathrm{ml}$ of $1 \mathrm{M} \mathrm{NaOH}$ and thereafter absorbance at $405 \mathrm{~nm}$ was determined. Phosphatase activity was defined as the amount of enzyme that released $1 \mu \mathrm{mol}$ p-nitrophenolate per min.

\subsection{Effect of media composition on phosphatase activity}

To study the effect of the composition of the growth medium on phosphatase activity, five different growth media were investigated. Soya peptone glucose medium (SPG) (25 $\mathrm{g} \mathrm{L}^{-1}$ soybean meal, $60 \mathrm{~g} \mathrm{~L}^{-1}$ glucose, $0.143 \mathrm{~g} \mathrm{~L}^{-1} \mathrm{ZnSO}_{4}$, $\left.\mathrm{pH} 7.5\right)$, yeast extractmalt extract (ISP2) (10 $\mathrm{g} \mathrm{L}^{-1}$ malt extract, $4 \mathrm{~g} \mathrm{~L}^{-1}$ yeast extract, $4 \mathrm{~g} \mathrm{~L}^{-1}$ glucose, $2 \mathrm{~g} \mathrm{~L}^{-1} \mathrm{CaCO}_{3}, \mathrm{pH}$ 7.4), Corn starch medium $\left(20 \mathrm{~g} \mathrm{~L}^{-1}\right.$ soybean meal, $40 \mathrm{~g} \mathrm{~L}^{-1}$ corn starch, $30 \mathrm{~g} \mathrm{~L}^{-1}$ dextrin, $2 \mathrm{~g} \mathrm{~L}^{-1}\left(\mathrm{NH}_{4}\right)_{2} \mathrm{SO}_{4}, 1 \mathrm{~g} \mathrm{~L}^{-1}$ $\left(\mathrm{NH}_{4}\right)_{2} \mathrm{HPO}_{4}, 8 \mathrm{~g} \mathrm{~L}^{-1} \mathrm{CaCO}_{3}, \mathrm{pH}$ 6.8), MGA and LuriaBertani broth $(\mathrm{LB}) \mathrm{v}\left(10 \mathrm{~g} \mathrm{~L}^{-1}\right.$ tryptone, $5 \mathrm{~g} \mathrm{~L}^{-1}$ yeast extract, $5 \mathrm{~g} \mathrm{~L}^{-1} \mathrm{NaCl}, \mathrm{pH} 7.0$ ) supplemented with $0.5 \%$ rice bran. The isolates were grown in each medium and after $60 \mathrm{hrs}$ phosphatase activity was determined.

\subsection{Statistical analysis}

To elucidate relationships among actinomycetes abundance, land use and climate variation, we compared actinomycete densities from different soil ecosystems. These encompassed four land use, wide range of climates (Arid, semi-Arid, Mediterranean, sub-Humid and Humid), because of differences in elevation and precipitation. Mean annual precipitation and temperature were based on 30 years averages from the meteorological stations and climate classification was based on de Marttone. Geographical information (latitude, longitude and elevation) was based on information from Global Positioning System (GPS). Statistical analysis and mean comparison using Duncan's test were conducted using SAS software (SAS Institute, 2000).

\section{Results and Discussion}

\subsection{Soil characteristics and actinomycetes population}

According to McCarthy and Williams (1992), organic matter, salinity, relative moisture, temperature, $\mathrm{pH}$ and vegetation are important factors which control abundance of actinomycetes in soil. A comparison of the mean values of the chemical and physical soil properties as well asthe actinomycetes population showed significant differences in $\mathrm{pH}$ value, organic carbon (OC), soil salinity expressed as electrical conductivity (EC) and actinomycetes number in the different soil ecosystems studied. Especially, climate variation had a significant effect on all mentioned parameters.

With the exception of forest soils, all studied soil ecosystems had a similar $\mathrm{pH}$ value $(\mathrm{pH} 7.7$ - 7.8) (Figure 1a). The $\mathrm{pH}$ value of the forest soil was significantly lower ( $\mathrm{pH}$ 6.92). The $\mathrm{pH}$ values found in this study are in good agreement with those reported by Khormali et al. (2009). They reported that the $\mathrm{pH}$ value increased from 7.2 to 7.5 when land use was changed from forest to agriculture. The apparently lower $\mathrm{pH}$ values observed in forest soils are due to a downward movement of basic ions in these soils. Natural processes such as carbon dioxide evolution from plant roots or soil microbial respiration are believed to be responsible for controlling soil $\mathrm{pH}$. Lauber et al. (2008) discussed that among others vegetation, soil type and soil management can alter soil $\mathrm{pH}$.

Soil organic matter has a key role on beneficial biological processes as well as on the chemical and physical properties of soils. It provides energy for soil microbial community, increases cation exchange capacity and ameliorates soil aggregate and structure (Wolf and Wagner, 2005). Organic carbon showed significant differences among the studies soil ecosystems. The average OC in forest soils was 4, 5 and 10 times higher than in irrigated, rain-fed and pasture soils, respectively (Figure 1b). These results 
Figure 1a

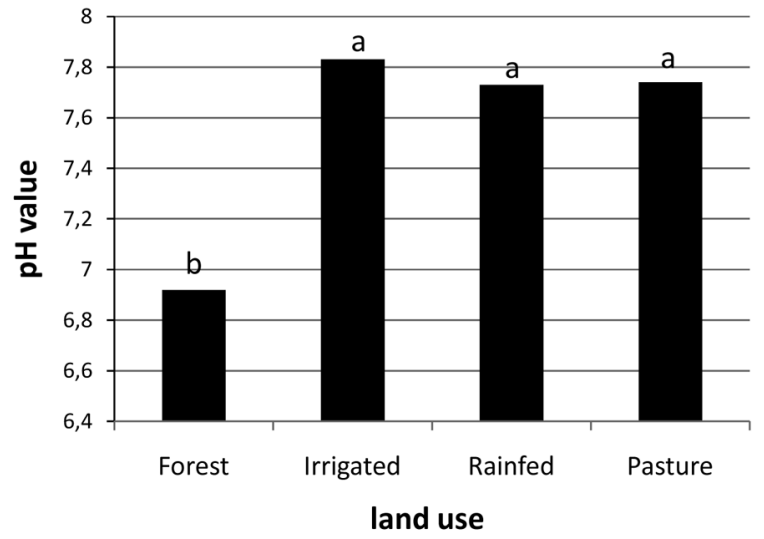

Figure 1b

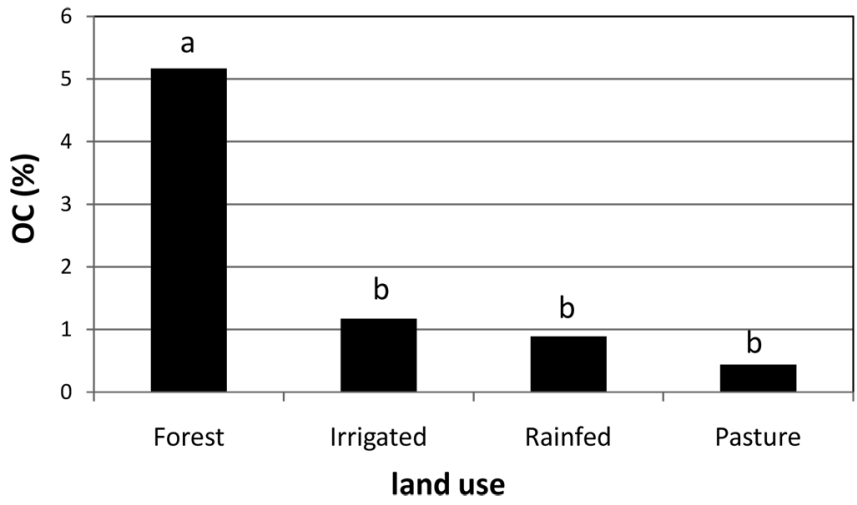

Figure 1c

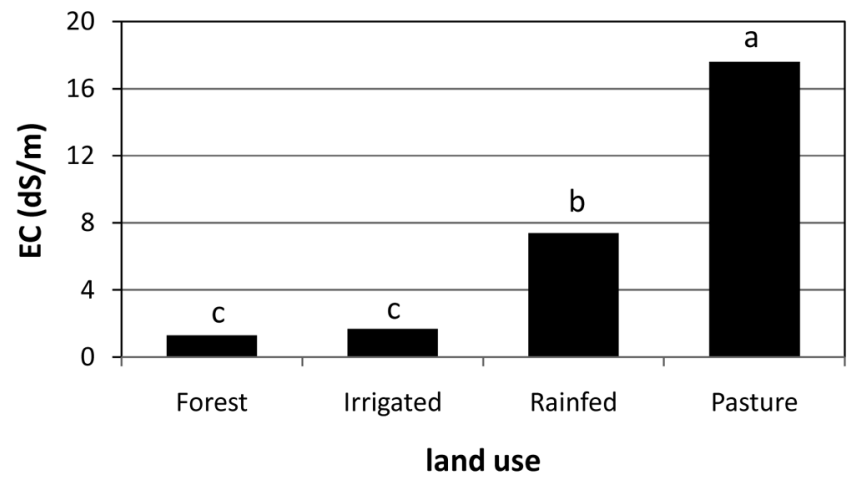


Figure 1d

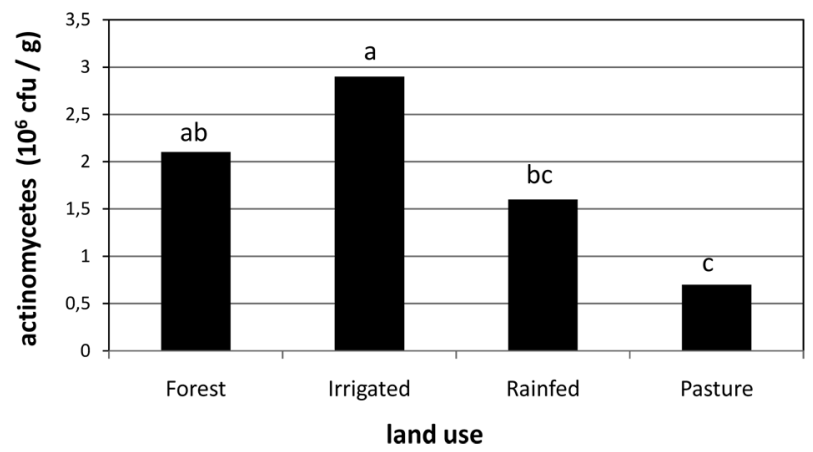

Figure 1: Mean values of the chemical and physical soil properties as well as the actinomycetes population in the different soil ecosystems studied (a) pH value, (b) organic carbon (OC), (c) soil salinity expressed as electrical conductivity (EC), (d) actinomycetes abundance columns with identical letters are not statistically different $(p<0.05)$

A strong decline in soil OC occurs after prolonged tillage (Burck et al., 1989), and rupture of the larger aggregates was reported to cause less protection of soil organic matter and to accelerate OC oxidation (Nardi et al., 1996).

Salinity is considered as a natural problem under arid and semi-arid conditions. Sensitive microorganisms are killed by high salt content, whereas some other microorganisms can adapt themselves to saline conditions. In this study, the lowest salinities were found in forest and irrigated soils. Salinity of the rainfed soil was intermediate and the highest salinity was observed in pasture (Figure 1c). Gennari et al. (2007) reported that the number of actinomycetes was $10^{5} \mathrm{cfu}$ $\mathrm{g}^{-1}$ soil in every soil studied, thus highlighting that the growth of actinomycetes was not affected by the salt content. Our results however suggest that the number of actinomycetes was affected by soil salinity when comparing the irrigated and rain-fed land uses.

To quantify actinomycetes numbers in different soil ecosystems dilution plate counts were used in many studies (Davis and Williams, 1970; Zhang et al., 2000).
Using this methodology, the community size can easily reach more than $10^{6} \mathrm{cfu} \mathrm{g}^{-1}$ soil which apparently cannot reflect actual numbers of actinomycetes in soil (Goodfellow and Williams, 1983). Nevertheless, the plate counts method was considered to be useful in the evaluation of the abundance of common actinomycetes in soil. Variation of actinomycetes abundance in the different soil ecosystems studied is shown in Figure 1d. The number of actinomycetes decreased from 2.86 $* 10^{6} \mathrm{cfu}^{-1}$ in irrigated cultivated land to $7 * 10^{5} \mathrm{cfu}$ $\mathrm{g}^{-1}$ in pasture $(p<0.01)$. In pastures, the number of actinomycetes was negatively correlated with soil salinity $(\mathrm{r}=-0.60, \mathrm{n}=15, p<0.001)$ and $\mathrm{pH}$ value $(\mathrm{r}=-$ $0.59, \mathrm{n}=15, p<0.001)$. The negative effect of salinity in soils of arid regions is characterized by a low amount of soil organic carbon. In other soil ecosystems under investigation no significant correlations between the parameters determined (soil $\mathrm{pH}, \mathrm{EC}$ ) and the number of actinomycete scould be found. Davis and Williams (1970), however, reported that soil $\mathrm{pH}$ and moisture content could affect actinomycetes population. The lowest numbers of actinomycetes were observed at high $\mathrm{pH}$ values and low moisture content. 


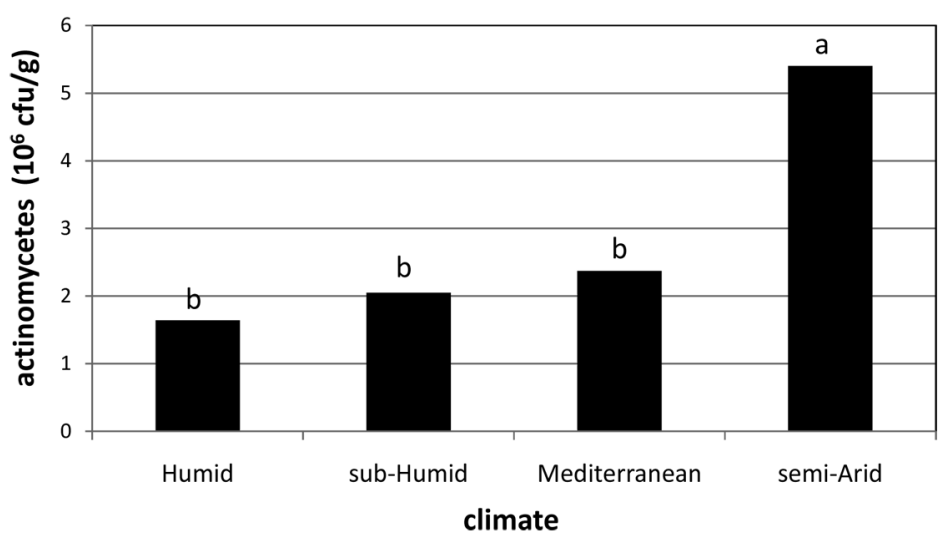

Figure 2: Effect of climate on actinomycetes population in forest land columns with identical letters are not statistically different $(p<0.05)$

In forest soils, the number of actinomycetes was significantly dependent $(p<0.05)$ on climate (Figure 2 ). A significantly higher population was observed under semi-arid conditions compared to all other climatic zones (humid, sub-humid, Mediterranean). Actinomycetes are not affected by semi-dry conditions as the majority of other soil bacteria and they prefer a relatively low level of moisture (Alexander, 1977). This property of actinomycetes might be due to their sporulation capability under drought conditions (ElTarabily and Sivasithamparam, 2006). The effect of climate onactinomycetes population in the other soil ecosystemsunder investigation was not significant.

Inositol phosphates, phospholipids and nucleic acids are the dominant forms of organic phosphorylated compounds in soils (Quiquampoix and Mousain 2005) and inositol phosphates have been reported to be the main form of organic phosphorus (Po) in soil (Dalal, 1977). Because actinomycetes are widely distributed in different soil ecosystems, it has been assumed that they are capable of hydrolyzing phytate (myo-inositol $(1,2,3,4,5,6)$ hexakisphosphate).
Very recently Ghorbani-Nasrabadi et al. (2012) gave proof for the validity of this assumption; all strains of actinomycetes under investigation were capable of producing extracellular phytatedegrading activity. Finally 67 isolates were confirmed to dephosphorylate phytatein liquid culture. Among these isolates 29, 36 and $35 \%$ originated from irrigatedcultivated, forest and rain-fed lands, respectively. According to phytate hydrolysis during fermentation, the actinomycetes were classified into 3 different groups. Members of Group 1 were reported as poor phytate degraders, members of group 2 produced considerable amounts of InsP3 to InsP5 during fermentation in the presence of phytate and members of group 3 were very efficient in phytate degradation. Due to the limited knowledge on regulation of phytase synthesis in actinomycetes a number of studies with a limited number of isolates under laboratory conditions were performed to obtain information about extracellular factors affecting the production of phytase and other phosphatases. 
Table 1: Effect of different nitrogen sources in the growth medium on phytate degradation with isolate No. 63 after 3 days of fermentation

\begin{tabular}{lcccc}
\hline $\mathrm{N}$-source & $\begin{array}{c}\text { InsP } \\
{[\%]}\end{array}$ & $\begin{array}{c}\text { InsP } \\
{[\%]}\end{array}$ & $\begin{array}{c}\text { InsP } \\
{[\%]}\end{array}$ & $\begin{array}{c}\text { InsP } \\
{[\%]}\end{array}$ \\
& & & & \\
& & & & \\
$\left(\mathrm{NH}_{4}\right)_{2} \mathrm{SO}_{4}$ & 89.98 & 7.96 & 0.54 & 1.52 \\
$\mathrm{NaNO}_{3}$ & 91.98 & 6.47 & trace & 1.55 \\
$\mathrm{NH}_{4} \mathrm{NO}_{3}$ & 92.83 & 4.09 & 1.98 & 1.10 \\
malt extract & 93.46 & 4.98 & 0.66 & 1.10 \\
meat extract & 50.50 & 44.90 & 2.78 & 0.90 \\
soybean meal & 92.22 & 6.26 & trace & 1.12 \\
arginine & 49.48 & 45.76 & 2.72 & 1.94 \\
\hline
\end{tabular}

Detection limit for allmyo-inositol phosphates was determined to be $10 \mu \mathrm{mol} / \mathrm{L}$. The initial sodium phytate concentration was 4 $\mathrm{g} / \mathrm{L}(4329 \mu \mathrm{mol} / \mathrm{L})$.

\subsection{Effect of different nitrogen and carbon sources on the phytate degradation}

Because it is well established that bacterial growth and production of phytate-degrading enzyme could be dependent on the composition of the growth medium (Fredrikson et al., 2002), the effect of the substitution of arginine or glycerol in the standard MGA medium on the phytate-degrading capability of the isolate with the highest extracellular phytate-degrading activity (No. 63) was investigated. Arginine was replaced by some inorganic (ammonium sulfate, ammonium nitrate, sodium nitrate) and some organic (malt extract, soybean meal) nitrogen sources and glycerol by simple sugars such as glucose, fructose, sucrose, lactose, and maltose and complex carbon sources such as pea flour and maltodextrin. A clear dependence of phytate degradation in the fermentation broth within 3 days of fermentation on the nitrogen source (Table 1) as well as the carbon source (Table 2) was observed. In general, substitution of arginine with the organic and inorganic nitrogen sources studied resulted in a significant reduction of phytate dephosphorylation (Table 1). 
Table 2: Effect of different nitrogen sources in the growth medium on phytate degradation with isolate No. 63 after 3 days of fermentation

\begin{tabular}{lcccc}
\hline C-source & & & & \\
& $\mathrm{InsP}_{6}$ & $\mathrm{InsP}_{5}$ & $\mathrm{Ins}_{4}$ & $\mathrm{Ins}_{3}$ \\
& {$[\%]$} & {$[\%]$} & {$[\%]$} & {$[\%]$} \\
\hline glucose & 89.76 & 9.22 & 0.32 & 0.71 \\
maltose & 91.96 & 6.48 & traces & 1.56 \\
lactose & 87.05 & 11.15 & traces & 1.80 \\
fructose & 81.11 & 16.21 & 1.25 & 1.43 \\
sucrose & 92.70 & 5.96 & traces & 1.34 \\
maltodextrine & 72.40 & 24.76 & 1.65 & 1.19 \\
pea flour & 60.28 & 32.96 & 4.58 & 1.73 \\
glycerol & 49.58 & 45.76 & 2.72 & 1.94 \\
\hline & & & & \\
\hline
\end{tabular}

detection limit for allmyo-inositol phosphates are indicated in $\mu \mathrm{mol} / \mathrm{lwas}$ determined to be $10 \mu \mathrm{mol} / \mathrm{L}$. The initial sodium phytate concentration was $4 \mathrm{~g} / \mathrm{L}(4329 \mu \mathrm{mol} / \mathrm{L})$.

With ammonium sulfate and sodium nitrate about $60 \%$ and with ammonium nitrate, malt extract and soybean meal about $40 \%$ of phytate hydrolysis compared to arginine was determined. This observation is in accordance with Ramachandran et al. (2005). They reported a reduction in fungal phytase production in the presence of sodium nitrate and ammonium sulfate. Substitution of arginine with meat extract however, did not have any effect on the capability of isolate No.63 to degrade the phytate present in the growth medium
(Table 1). Replacing glycerol in the standard MGA medium by glucose, maltose and sucrose did almost completely suppress phytate dephosphorylation (Table 2). With fructose about $70 \%$ and with lactose and maltodextrin about $50 \%$ of phytate hydrolysis compared to glycerol was observed. Substitution of glycerol with pea flour however, did not have any effect on the capability of isolate No. 63 to degrade the phytate present in the growth medium. 
Table 3: Acid and alkaline phosphatase activity in different actinomycetes isolates in standard MGA medium

\begin{tabular}{ccc}
\hline Isolate No. & $\begin{array}{c}\text { Acid phosphatase } \\
\left(\mathrm{mU} \mathrm{ml}^{-1}\right)\end{array}$ & $\begin{array}{c}\text { Alkaline phosphatase } \\
\left(\mathrm{mUml}^{-1}\right)\end{array}$ \\
\hline 39 & $13.5 \mathrm{a}$ & $18.16 \mathrm{~b}$ \\
43 & $1.12 \mathrm{f}$ & $0.59 \mathrm{e}$ \\
44 & $0.92 \mathrm{~g}$ & $1.37 \mathrm{~d}$ \\
45 & $5.23 \mathrm{~d}$ & $1.37 \mathrm{~d}$ \\
46 & $1.56 \mathrm{e}$ & $1.32 \mathrm{~d}$ \\
47 & $0.99 \mathrm{fg}$ & 0 \\
50 & $8.27 \mathrm{~b}$ & $27.59 \mathrm{a}$ \\
63 & $6.74 \mathrm{c}$ & $3.02 \mathrm{c}$ \\
\hline
\end{tabular}

numbers with identical letters are not significantly $(p<0.05)$ different

\subsection{Acid and alkaline phosphatase activity}

In order to make the organic phosphorus pool in soil available for plants and soil microorganism, the organically bound phosphate must be released. Because plant roots do not exude significant amounts of phosphatases including phytases, it was assumed that soil microorganisms may play an important role in this process. Release of organically bound phosphate is a concerted action of phytases and other phosphatases and therefore the eight actinomycetes isolates,among the 67 isolates confirmed by GhorbaniNasrabadi et al. (2012) to dephosphorylate phytate in liquid culture, with the highest capability to produce extracellular phytaseswere studied in respect to their extracellular acid and alkaline phosphatase activity (Table 3). A huge variation in the capacity to produce acid and alkaline phosphatases among the different isolates was observed. Neither the capacity to produce acid nor the capacity to produce alkaline phosphatases did correlate with the phytate-degrading capacity. The highest extracellular phytate-degrading activity was observed with isolate No.63, whereas the highest acid phosphatase activity was found with isolate No. 39 and the highest alkaline phosphatase activity with isolate No. 50. 
Table 4: Effect of media composition on acid and alkaline phosphatase activity in isolate No. 63

\begin{tabular}{lcc}
\hline Medium & $\begin{array}{c}\text { Acid phosphatase } \\
\left(\mathrm{mUml}^{-1}\right)\end{array}$ & $\begin{array}{c}\text { Alkaline phosphatase } \\
\left(\mathrm{mUml}^{-1}\right)\end{array}$ \\
\hline SPG & $34.0 \mathrm{a}$ & $5.01 \mathrm{a}$ \\
MGA & $6.74 \mathrm{~b}$ & $3.02 \mathrm{~b}$ \\
ISP2 & 0 & 0 \\
LB+ rice bran & $3.34 \mathrm{c}$ & $0.75 \mathrm{c}$ \\
Corn starch & $1.97 \mathrm{~d}$ & 0 \\
& & \\
\hline
\end{tabular}

numbers with identical letters are not significantly $(p<0.05)$ different

\subsection{Effect of media composition on phosphatase activity}

It is well documented that expression of phosphatases in microorganisms is strongly affected by medium composition (Pedregosa et al., 1991). Different media were used to evaluate the effect of medium composition on extracellular acid and alkaline phosphatase activities of isolate No. 63 and it was confirmed that these enzyme activities are dependent on the medium used for fermentation (Table 4). However, acid and alkaline phosphatase activities were affected differently by medium composition. In SPG, for example, acid phosphatase activity was 5-fold higher compared to ISP2, whereas alkaline phosphatase activity was only 1.7-fold higher. In MGA both acid and alkaline phosphatase activities were below the detection limit of the enzyme activity assays.

\section{Conclusion}

Actinomycetes are one of the predominant members of soil microbial communities and they have beneficial roles in soil nutrients cycling and agricultural productivity (Elliot and Lynch, 1995). With the exception of pasture, soil factors such as $\mathrm{pH}$ and salinity do not significantly affect actinomycetes population in the different soil ecosystems studied. The effect of salinity on microbial biomass and activity is not uniform and the observed differences may be due to the composition of the pool of soluble ions as well as the presence or absence of plant and agricultural activities. In this study no significant difference in the number of actinomycetes was observed comparing irrigated and rain-fed land uses, even though electrical conductivity was significantly different $(p<0.05)$. This observation supports the conclusion of Chowdhury et al. (2011) that the combined effects of matric and osmotic potential in saline soils is more important for microbial biomass 
than electrical conductivity. In addition, the knowledge on the participation of actinomycetes in hydrolysis of organic phosphorylated compounds is extremely limited. It went clear that production of phytases and other phosphatases is strongly dependent on the actinomycetes strain as well as media composition. Furthermore, production of phytases, acid phosphatases and alkaline phosphatases was shown to be regulated independently. However, the importance of actinomycetes in dephosphorylation of soil organic compounds needs to be elucidated in further studies.

\section{References}

Alexander, M. 1977. Introduction to soil microbiology, 2nd edition, Krieger Publishing Company, USA.

Bossio, D.A., Girvan, M.S., Verchot, L., Bullimore, J., Borelli, T., Albrecht, A., Scow, K.M., Ball, A.S., Pretty, J.N., Osborn, A.M. 2005. Soil microbial community response to land use change in an agricultural landscape of Western Kenya. Microbial Ecology. 49, 50-62.

Burck, I.C., Yonker, C.M., Parton, W.J., Cole, C.V., Flach, K., Schimel, D.S. 1989. Texture, climate, and cultivation effects on soil organic matter content in USA grassland soils. Journal of Soil Science Society of America. 53, 800-805.

Chowdhury, N., Marschner, P., Burns, R.G. 2011. Soil microbial activity and community composition: impact of changes in matric and osmotic potential. Soil Biology and Biochemistry. 43, 1229-1236.

Dalal, R.C. 1977. Soil organic phosphorus. Advances in Agronomy. 29, 83-117.

Davies, F.L., Williams, S.T. 1970. Studies on the ecology of actinomycetes in soil I. The occurrence and distribution of actinomycetes in a pine forest soil. Soil Biology and Biochemistry. 2, 227-238.

Elliot, L.F., Lynch, J.M. 1995. The international workshop on establishment of microbial inocula in soils: cooperative research project on biological resource management of the Organization for Economic Cooperation and Development (OECD). American Journal of Alternative Agriculture.10, 50-73.

El-Nakeeb, M.A., Leachevalier, H.A. 1963. Selective isolation of aerobic actinomycetes. Applied Microbiology. 11, 75-77.

El-Tarabily, K.A., Sivasithamparam, K. 2006. Nonstreptomyceteactinomycetes as biocontrol agents of soil-borne fungal plant pathogens and as plant growth promoters. Soil Biology and Biochemistry. $38,1505-1520$.

Fierer, N., Carney, K.M., Horner-Devine, M.C., Megonigal, J.P. 2009. The biogeography of ammonia-oxidizing bacterial communities in soil. Microbial Ecology. 58, 435-445.

Fredrikson, M., Andlid, T., Haikara, A., Sandberg, A.S. 2002. Phytate degradation by micro-organisms in synthetic media and pea flour. Journal of Applied Microbiology. 93, 197-204.

Gee, G.W., Bauder, J.W. 1986. Particle-size analysis,in: A. Klute (Ed.), Methods of Soil Analysis, Part 1. Physical and Mineralogical Methods, 2nd edition.

Ghorbani-Nasrabadi, R., Greiner, R., Alikhani, H. A., Hamedi, J. 2012. Identification and determination of extracellular phytate-degrading activity in actinomycetes. World Journal of Microbiology and Biotechnology. 28, 2601-2608.

Goodfellow, M., Williams, S.T. 1983. Ecology of actinomycetes. Annual Review of Microbiology. 37, 189-216

Greiner, R., Jany, K.D. 2003. Purification and characterisation of homogeneous acid phosphatase without phytate-degrading activity from nongerminated buck wheat (Fagopyrumesculentum) seeds. Journal of Food Biochemistry. 27, 197-220. 
Greiner, R., Konietzny, U., Jany, K.D. 2007. Purification and properties of a phytase from rye. Journal of Food Biochemistry. 22, 143-161.

Hamdali, H., Hafidi, M., Virolle, M.J., Ouhdouch,Y. 2008. Growth promotion and protection against damping-off of wheat by two rock phosphate solubilizing actinomycetes in a P-deficient soil under greenhouse conditions. Applied Soil Ecology. 40, 510-517.

Harrison, A.F. 1987. Soil organic phosphorus. A review of world literature. Oxford CAB International.

Khormali, F., Ajami, M., Ayoubi, S., Srinivasarao, Ch., Wani S.P. 2009. Role of deforestation and hillslope position on soil quality attributesof loess-derived soils in Golestan province, Iran. Agriculture, Ecosystems \& Environment. 134, 178-189.

Lauber, C.L., Hamady, M., Knight, R., Fierer, N. 2009. Pyrosequencing-based assessment of soil $\mathrm{pH}$ as a predictor of soil bacterial community structure at the continental scale. Applied and Environmental Microbiology. 75, 5111-5120.

McCarthy, A.J., Williams, S.T. 1992. Actinomycetes as agents of biodegradation in the environment - a review. Gene. 115, 189-192.

McLean, E.O. 1982. Soil $\mathrm{pH}$ and lime requirement,in: A.L. Page, A.L., R.H. Miller, D.R. Keeney (Eds.), Methods of Soil Analysis, Part 2. Chemical and Microbiological Properties, 2nd edition.

Nardi, S., Cocheri, G., Dell Agnola, G. 1996. Biological activity of humus, in: A. Piccolo (Ed.), Humic Substances in Terrestrial Ecosystems. Elsevier, Amsterdam pp. 361-406.

Nelson, D.W., Sommers, L.E. 1982. Total carbon, organic carbon, and organic matter, in: A.L. Page, R.H. Miller, D.R. Keeney (Eds.), Methods of Soil Analysis, Part 2. Chemical and Microbiological Properties. 2nd edition.
Ouahmane, L., Thioulouse, J., Hafidi, M., Prin, Y., Ducousso, M., Galiana, A., Plenchette, C., Kisa, M., Duponnois, R. 2007. Soil functional diversity and $\mathrm{P}$ solubilization from rock phosphate after inoculation with native or mycorrhizal fungi. Forest Ecology and Management. 241, 200-208.

Pedregosa, A.M., Pinto, F., Monistrol, I.F., Laborda, F. 1991. Regulation of acid and alkaline phosphatases of Cladosporiumcucumerinumby inorganic phosphate. Mycological Research. 95, 720-724.

Peix, A., Rivas-Boyero, A.A., Mateos, P.F., Rodriguez-Barrueco, C., Martinez-Molina, E., Velazquez, E. 2001. Growth promotion of chickpea and barley by a phosphate solubilizing strain of Mesorhizobiummediterraneum under growth chamber conditions. Soil Biology and Biochemistry. 33, 103-110.

Puget, P., Lal, R. 2005. Soil organic carbon and nitrogen in a Mollisol in central Ohio as affected by tillage and land use. Soil and Tillage Research. 80. 201-213.

Quiquampoix, H., Mousain, D. 2005. Enzymatic hydrolysis of organic phosphorus, in: B.L. Turner, E. Frossard, D.S. Baldwin (Eds), Organic phosphorus in the environment, CABI, UK. pp. 89-112.

Ramachandran, S., Krishnan, R., Nampoothiri, K.M., Szackacs, G.,Pandey, A. 2005. Mixed substrate fermentation for the productionof phytase by Rhizopus spp. using oil cakes as substrates. Process Biochemistry. 40, 1749-1754.

Rodriguez, H., Fraga, R. 1999. Phosphate solubilizing bacteria and their role in plant growth promotion. Biotechnology Advances. 17, 319-339.

Ryan, J., Garabet, S., Rashid, A., El Gharous, M. 1999. Assessment of soil and plant analysis laboratories in the West Asia-North Africa Region. Communications in Soil Science and Plant Analysis. 30, 885-894. 
Sandberg, A.S., Ahderinne, R. 1986. HPLC method for determination of inositol tri-, tetra-, penta-, hexaphosphates in foods and intestinal contents. Journal of Food Science. 51, 547-550.

SAS Institute.2000. SAS Online Doc. Version 8. SAS Inst., Cary, NC. available at: http://v8doc.sas.com/ sashtml/> (accesses 02.04.08; verified 23.02.04).

Van Vuuren, D.P., Bouwman, A.F., Beusen, A.H.W. 2010. Phosphorus Demand for 1970-2100 Period: A Scenario Analysis of Resource Depletion, Global Environmental Change. 20, 428-439.

Williams, S.T., Wellington, E.M.H. 1982. Principles and problems of selective isolation of microbes, in: J.D. Bullock, L.J. Nisbet, D.J. Winstanley (Eds.), Bioactive Microbial Products 1: Search and Discovery, Academic Press, UK pp. 9-26.
Wolf, D.C., Wagner, G.H. 2005. Carbon transformations and soil organic matter formation, in: D.M. Sylvia, J.J. Fuhrmann, P.G. Hartel, D.A. Zuberer (Eds.), Principles and applications of soil microbiology. Pearson Prentice Hall, USA pp. 285-332.

Zheng, Z., Zeng, W., Huang, Y., Yang, Z., Li, J., Cai, H., Su, W. 2000. Detection of antitumor and antimicrobial activities in marine organism associated actinomycetes isolated from the Taiwan Strait, China. FEMS Microbiology Letters. 188, 87-91. 